\title{
Transanal Minimally Invasive Surgery (TAMIS) Using Single Incision Laparoscopic Surgery (SILS) Port for the Management of Benign Rectal Neoplasms: A Single Center Study
}

\author{
SiLS Port Kullanılarak Yapılan Transanal Minimal İnvaziv Cerrahi (TAMIS): \\ Tek Merkez Kısa Dönem Sonuçları
}

\author{
(1) Tevfik Kıvılcım Uprak, (1) Wafi Attaallah \\ Marmara University Faculty of Medicine, Department of General Surgery, İstanbul, Turkey
}

\section{HIIIIII| ABSTRACT}

\begin{abstract}
Aim: Conventional transanal excision was described decades ago for treatment of benign rectal neoplasms. However, the chalanges of this technique leads to use alternative approachs. We evaluated the results of transanal minimally invasive surgery (TAMIS) with single incision laparoscopic surgery (SILS) port in treatment of benign rectal neoplasms.

Method: Data of the patients who underwent TAMIS with SILS port in one center were retrospectively analyzed. SILS port was placed through in the anal canal and ultrasonic sealing device was used for excision the tumors. Complications during or after surgery were reported. Patients were followed-up by rectal examination with rectoscopy and recurrences were evaluated.

Results: Between July 2015 and March 2020, 20 patients underwent TAMIS at one center. The median age of the patients was 67 (37-79). The procedure was performed in all of the patients with a lithotomy position. Full-thickness defect after complete resection of the lesion was observed in $5(25 \%)$ patients. However, abdominal cavity was not exposed through the TAMIS procedure in any of the patients. The rectal wall defect was not repaired in any of the patients. No major complication occured in the patients. The hospital stay was 1 (1-4) days. The surgical margin was negative in 19 patients (95\%). After the follow-up period of 9 (1-43) months, 3 (17\%) patients had a recurrence and further surgery was performed.
\end{abstract}

Conclusion: TAMIS using SILS port for the management of rectal neoplasms is a safe and effective for treatment benign rectal lesions.

Keywords: Rectal adenoma, single-incision laparoscopic surgery port, TAMS

\section{|IIIIIII ÖZ}

Amaç: Benign rektal neoplazmların tedavisi için geleneksel transanal eksizyon on yıllar önce tanımlanmıştır. Bununla birlikte, bu tekniğin zorlukları, alternatif yaklaşımların kullanılmasına yol açar. Bu çalışmada benign rektal neoplazmların tedavisinde tek insizyon laparoskopik cerrahi (SILS) portu ile transanal minimal invaziv cerrahi (TAMIS) sonuçlarını değerlendirdik.

Yöntem: Merkezimizde SILS portu ile TAMIS uygulanan benign rektal neoplazmalı hastaların verileri retrospektif olarak incelendi. SILS portu anal kanal içerisine yerleştirildi ve tümörlerin eksizyonu için ultrasonik mühürleme cihazı kullanıldı. Ameliyat sırasında veya sonrasında komplikasyonlar rapor edildi. Hastalar proktoskopi ve rektal muayene ile takip edilerek nüksler değerlendirildi.

Bulgular: Temmuz 2015 ile Mart 2020 arasında 20 hastaya TAMIS uygulandı. Hastaların ortanca yaşı 67 (37-79) idi. Tüm hastalarda litotomi posizyonunda ameliyat edildi. 5 (\%25) hastada lezyonun tam olarak çıkarılmasından sonra tam kat defekt görüldü. Ancak hiçbir hastada abdominal boşluğa girilmedi. Hiçbir hastada rektal duvar defekti onarılmadı. Hastalarda majör komplikasyon izlenmedi. Hastanede kalış süresi 1 (1-4) gündü. 19 hastada (\%95) cerrahi sınır negatifti. 9 (1-43) aylık takip süresinden sonra 3 (\%17) hastada nüks görüldü ve ileri cerrahi yapıldı.

Sonuç: Rektal neoplazmların yönetimi için SILS portunu kullanılan TAMIS, benign rektal lezyonların tedavisi için güvenli ve etkilidir.

Anahtar Kelimeler: Rektal adenom, transanal minimal invaziv cerrahi, TAMİS

Address for Correspondence/Yazışma Adresi: Wafi Attaallah, MD,

Marmara University Faculty of Medicine, Department of General Surgery, İstanbul, Turkey

E-mail: drwafi2003@yahoo.com ORCID ID: orcid.org/0000-0002-3179-4144

Received/Geliş Tarihi: 15.10.2020 Accepted/Kabul Tarihi: 23.12.2020

${ }^{\circ}$ Copyright 2021 by Turkish Society of Colon and Rectal Surgery

Turkish Journal of Colorectal Disease published by Galenos Publishing House. 


\section{Introduction}

Transanal excision (TAE) was described decades ago for the treatment of early-stage rectal cancers and benign neoplasia of the rectum. However, this conventional approach has some limitations such as difficult accessibility in some tumour locations, and difficulties may occur during surgery. This approach limited the surgeon's ability to perform highquality oncological excisions. Therefore, minimally invasive techniques were introduced as an alternative approach to overcome the disadvantages of conventional TAE. One of the minimally invasive techniques was transanal endoscopic microsurgery, which was introduced in early 1980s; since then, it demonstrated greater effectiveness than traditional TAE for the resection of rectal masses. ${ }^{2}$ However, some limitations and disadvantages such as cost-effectiveness and specialised instrumentation requirements limit the widespread use of this technique. Therefore, transanal minimally invasive surgery (TAMIS) was described more recently as an alternative and more cost-effective technique with similar function. ${ }^{3}$ Intraluminal full-thickness excision of rectal neoplastic lesions can be achieved easily by TAMIS. This technique is cost effective and does not require special instruments; thus, it was described as a giant leap forward in this field. ${ }^{4}$

In this study, we evaluated the short-term outcomes of patients with benign rectal neoplasms who underwent TAMIS using the single-incision laparoscopic surgery (SILS) port in a single centre.

\section{Method}

Data of patients with benign rectal neoplasm who underwent rectal lesion excision using TAMIS in one centre were retrospectively analysed. Patients who underwent colonoscopic evaluation and pathological confirmation for adenoma that cannot be removed with colonoscopy were included in this study. Patients who have undergone rectal surgery, diagnosed with rectal cancer, and declined surgery by TAMIS technique were excluded. Preoperative workup including digital rectal examination, complete blood count, liver function tests, coagulation profiles and total colonoscopy was performed in all patients. The distance from the anal verge was measured during colonoscopy. All procedures were carried out after obtaining informed consent from the patients. Antithrombotic prophylaxis by low-molecular-weight heparin and mechanical bowel preparation was applied in all patients before surgery.

This study was approved by Marmara University Faculty of Medicine Ethics Committee, and all patients provided written informed consent.

\section{TAMIS Technique}

The patient was placed in the lithotomy position, general anaesthesia was inducted and anal dilatation was subsequently performed. The SILS port (Covidien, Mansfield, MA, USA) was placed through the anal canal and fixed to the anoderm by four stiches with No. 1 silk sutures in four different sides (Figure 1). Pneumorectum was established with $\mathrm{CO}_{2}$ insufflation through the SILS port. A 5-mm $30^{\circ}$ laparoscopic camera was inserted through the 5-mm trocar. The rectum was explored up to the upper part. Then, the mucosa adjacent to the tumour was grasped by a non-rotaticulated grasper to elevate the lesion (Figure 2). Laparoscopic harmonic scalpel (Ultracision ${ }^{\mathrm{TM}}$, Model HAR 36, Ethicon Endo-surgery, Cincinnati, OH, USA) was used for tumour dissection and excision (Figure 3). After haemostasis was completed, the specimen and the single port were removed simultaneously (Figures 4 and 5). Demographic characteristics, tumour localisation, pathological features, postoperative mortality, morbidity and recurrence rates were analysed. Patient follow-up was performed according to the pathological examination results of the specimen. Patients with benign pathology were followed up by rectal examination and rectoscopy every 3 months in the first year and every 6 months in the second year. Colonoscopy was performed annually after the second year for patients without any recurrences. Patients diagnosed with cancer based on the definitive pathological report or developed recurrent adenoma undergo further surgery by low anterior resection or abdominoperineal resection (APR).

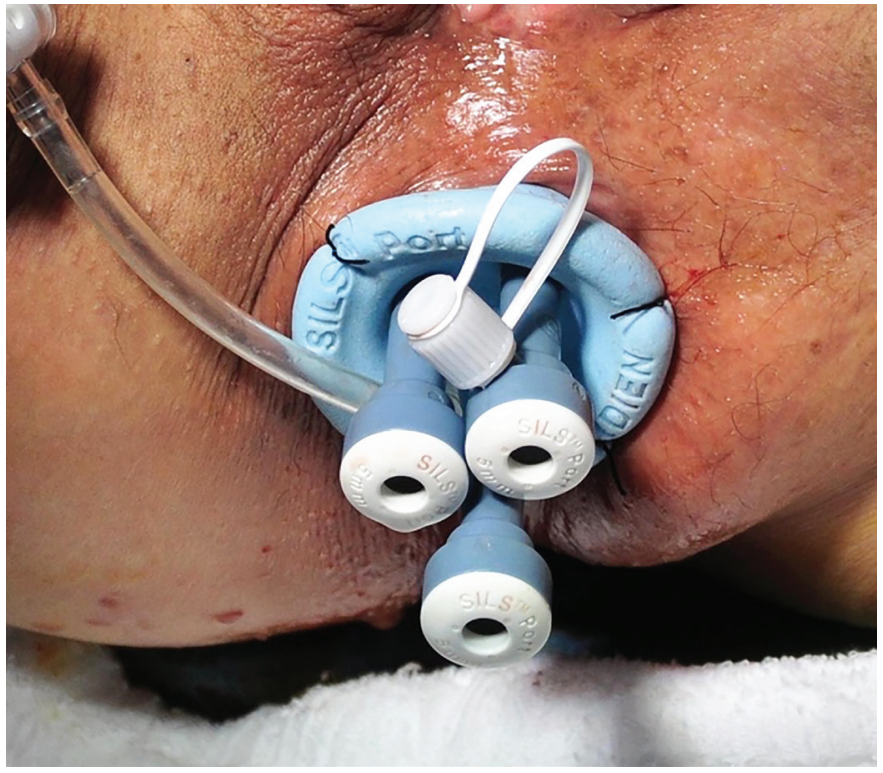

Figure 1. Single-incision laparoscopic surgery port was placed through the anal canal 


\section{Results}

Between July 2015 and March 2020, 20 patients with rectal adenoma who were admitted to Marmara University General Surgery Department were eligible for the TAMIS technique. The median age of the patients was 67 (3779) years, and 10 (50\%) were male. The most common presentation of the patients was rectal bleeding ( $n=9,45 \%)$, followed by constipation and anaemia. Tenesmus, pain and mucus defecation were less common symptoms upon presentation. The median distances of the rectal tumours

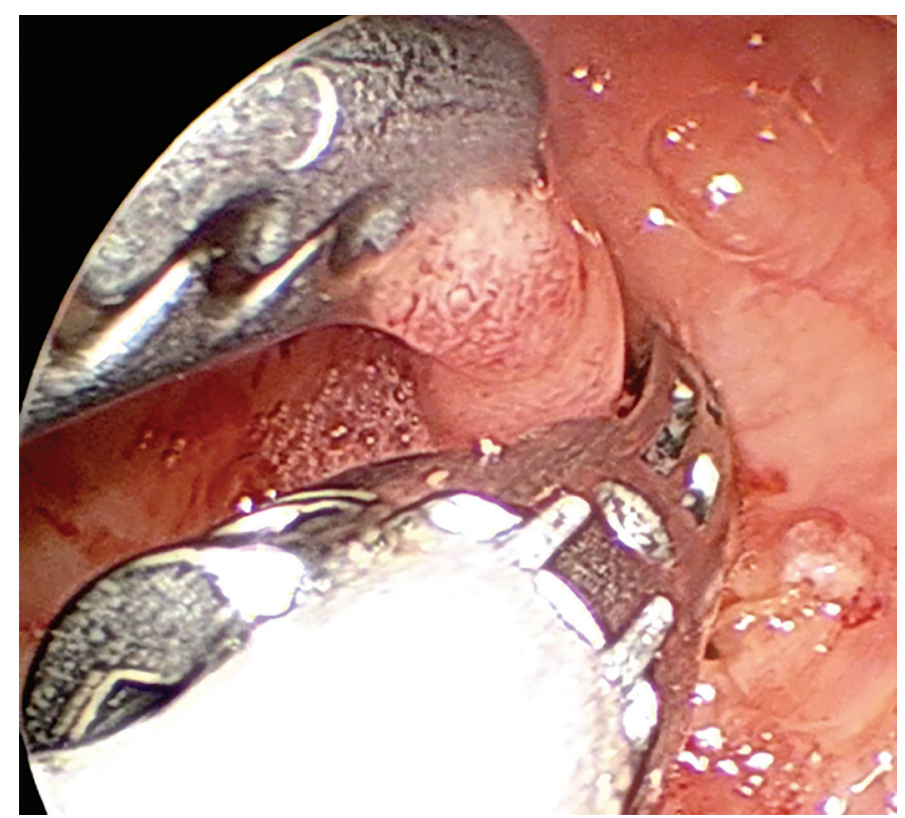

Figure 2. Elevation of the lesion using a non-rotaticulated grasper

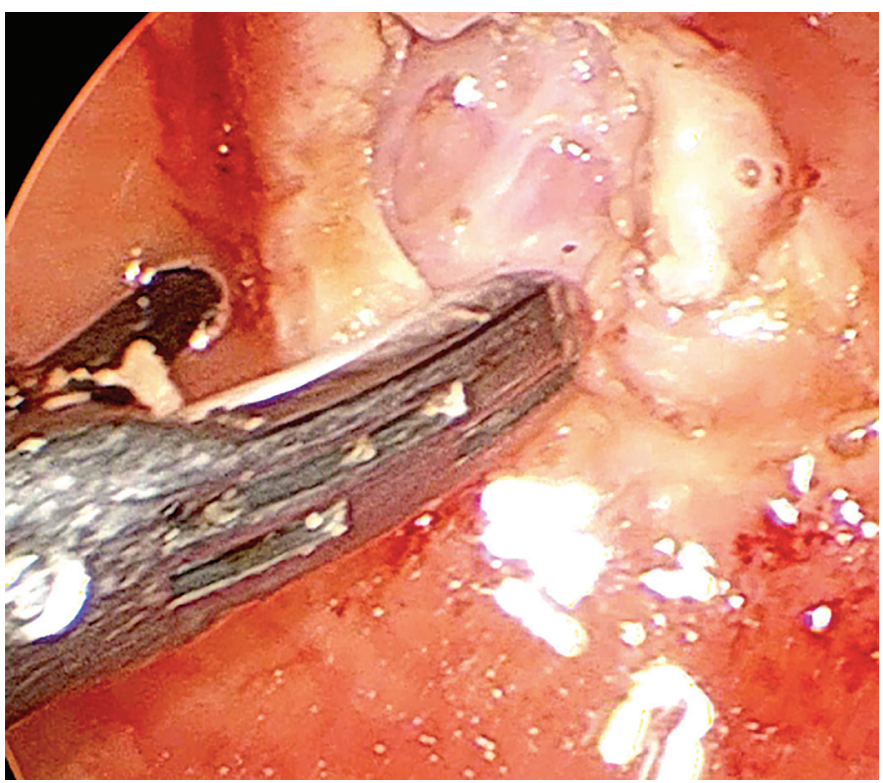

Figure 3. Dissection and excision the tumour using laparoscopic ultrasonic sealing device from the anal verge were $6.4(2-10) \mathrm{cm}$. The median tumour diameter was $3(2-5) \mathrm{cm}$. Pathology reports of colonoscopic biopsies revealed tubulovillous adenoma in all patients. The American Society of Anaesthesiologist (ASA) score was 1 or 2 in most (82\%) patients. Full-thickness defect after complete resection of the lesion was described by exposing the perirectal adipose tissue, which was observed in 5 (25\%) patients (Figure 6). However, the abdominal cavity was not exposed through the TAMIS procedure in any of the patients. The rectal wall defect was not repaired in any of the patients. Postoperative computed tomography of cases with full-thickness defects showed free air at the perirectal area, but free abdominal air was not observed in any of them. TAMIS was not converted to open or laparoscopic surgery. Oral nutrition was started on the first postoperative

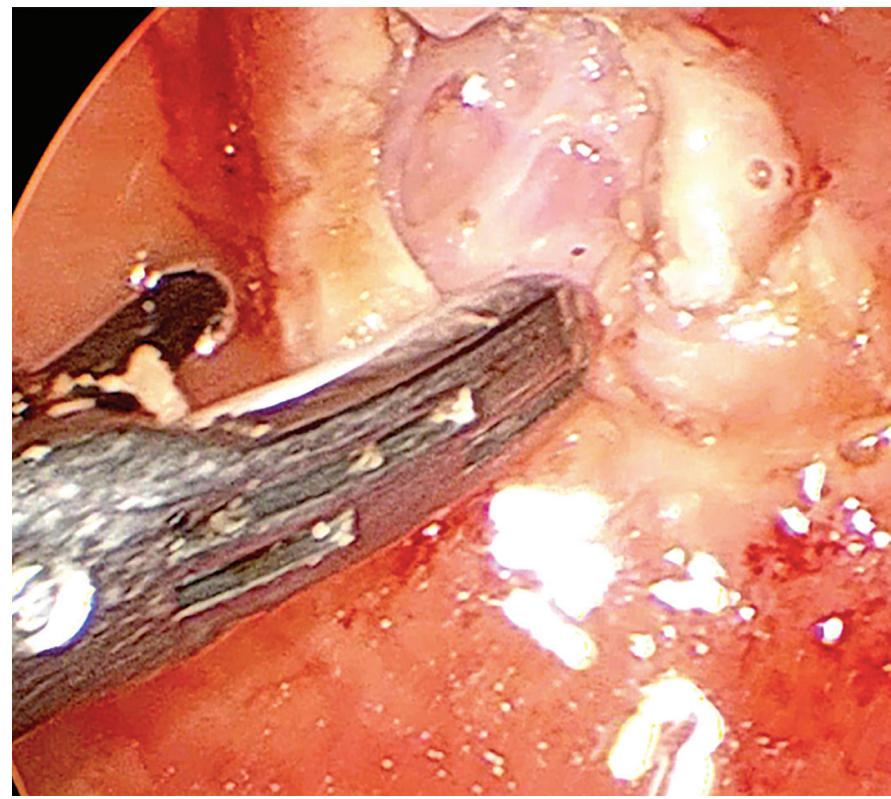

Figure 4. After complete excision, the tumour was grasped and removed together with the single port

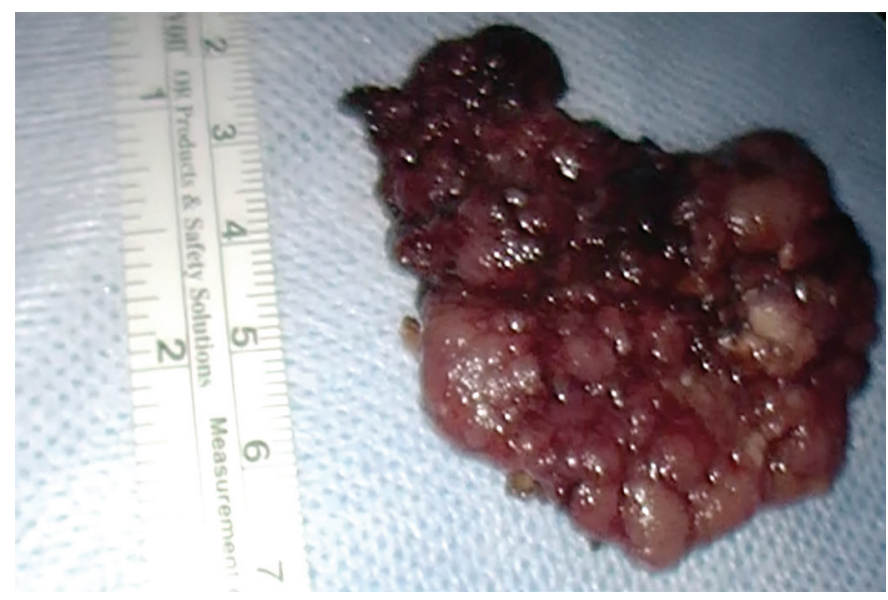

Figure 5. Macroscopic view of the specimen 


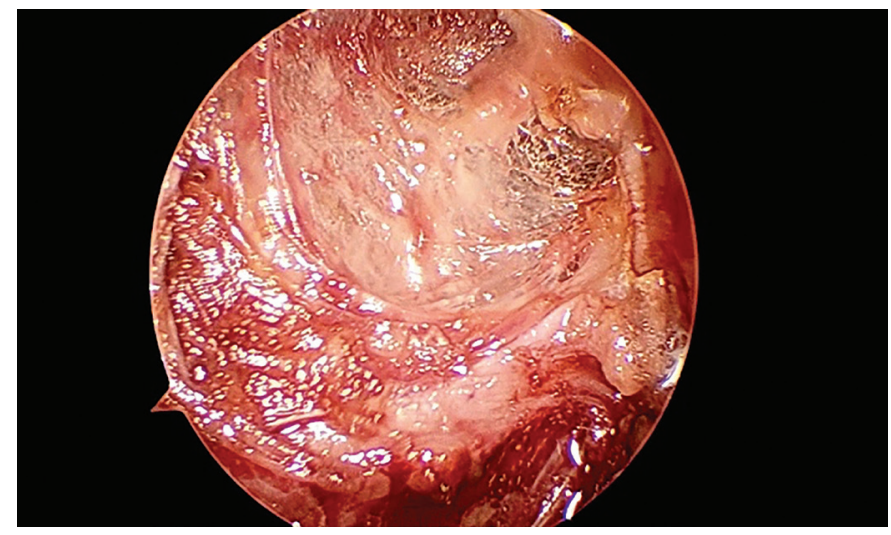

Figure 6. Full-thickness defect after complete resection of the lesion

day in all patients. The median hospital stay was 1 (1-3) days. Scrotal emphysema occurred in two patients, which resolved spontaneously. The definitive pathology reports revealed adenocarcinoma in two (10\%) patients after TAMIS. APR was performed in one patient, and the final pathology was ulcer, fibrosis with tumour negative 9 lymph node. In the other patient, a stage T1 tumour was found, and follow-up without surgery was preferred due to the old age and poor general condition of the patient. Positive surgical margin was reported in 1 (5\%) patient. The median followup duration was 9 (1-43) months. Moreover, 3 (15\%) patients had a recurrence of adenoma during the followup. However, TAMIS was not attempted again because we thought that a repeat TAMIS will be a high-risk procedure. Therefore, low anterior resection was performed for all of them (Table 1).

\section{Discussion}

In this study, outcomes of 20 patients who underwent TAMIS using the SILS port for the treatment of benign rectal tumours in one centre were evaluated. Results showed that this approach is safe and effective and has favourable outcomes within a short follow-up period. Inclusion of consecutive patients to prevent selection bias and the use of the SILS port as standard and a single energy source in all patients are considered the strengths of this study.

The literature has not established indication of TAMIS in terms of age, gender or ASA classification. Patients up to age 90 years can successfully undergo TAMIS. ${ }^{5}$ Previous studies with high-volume series showed $4 \%-20 \%$ of cases with positive surgical margin after TAMIS. ${ }^{6}$ Positive surgical margin was observed particularly in patients with anterior lesions who underwent surgery in the lithotomy position and in first few cases performed during the learning curve. ${ }^{7}$ In the present study, the positive margin rate was low (5\%), which was compatible with the literature. Recent studies
Table 1. Demographic features and outcomes of all the patients

$\begin{array}{ll}\text { Median age (years) } & \mathrm{N}=20 \\ \text { Gender } & 67(37-79) \\ \text { Male } & \\ \text { Female } & 10(50 \%) \\ \text { ASA score } & 10(50 \%) \\ & 7(35 \%) \\ & 11(55 \%) \\ & 2(10 \%) \\ & 0\end{array}$

Presentation symptom

Rectal bleeding $9(45 \%)$

Constipation $\quad 5(25 \%)$

Anemia $5(25 \%)$

Abdominal pain $4(20 \%)$

No symptom (diagnosis during screening 3 (15\%) colonoscopy)

Weight loss $\quad 1(5 \%)$

Anal pain $1(5 \%)$

Tenesmus $1(5 \%)$

Median tumor distance from the anal verge $6.4(2-10)$

(min-max) (cm)

Complications

Hemorrhage $\quad 0(0 \%)$

Urinary retention $\quad 0(0 \%)$

Perirectal abscess $\quad 0(0 \%)$

Scrotal emphysema $2(10 \%)$

Median length of hospital stay (min-max) (days) $\quad 1$ (1-4)

Follow-up (months) 9 (1-43)

Positive surgical margin $\quad 1(5 \%)$

Tumor recurrence 3(15\%)

ASA: American Society of Anaesthesiologist, min: Minimum, max: Maximum

have shown $6 \%-22 \%$ of recurrence after TAMIS. $3,5,6,8$ In the present study, recurrence was observed in $3(15 \%)$ patients, which is similar to rates reported previously. Some studies have also reported that TAMIS can be performed for lesions located 3-15 cm from the anal verge. ${ }^{8,9,10,11}$ However, in the present study, TAMIS was performed for lesions including those located $2 \mathrm{~cm}$ to the anal verge. There was no consensus about the size of lesions eligible for TAMIS. Previous studies with a large sample size have reported a median lesion 
diameter of $3.1(0.8-4.75) \mathrm{cm}^{.}$Similarly, in the present study, the median lesion diameter was $3(2-5) \mathrm{cm}$.

Because of the possibility of an invasive component, fullthickness excision was considered necessary when local excision was performed for malignant lesions. ${ }^{7}$ Some previous studies have suggested that lesions with malignant characteristics should be treated with full-thickness resection without compromising the deep plane of the tumour and that $1 \mathrm{~mm}$ negative margin is sufficient for adenomas. Therefore, preoperative evaluation of lesions is important. ${ }^{12}$ Strict patient selection is required to optimise results. Lee et al. ${ }^{6}$ developed an algorithm, and TAMIS was performed for curative purposes if the lesion was benign or had no high-risk features. In the present study, full-thickness excision was not attempted since all analysed patients have rectal adenoma diagnosis confirmed by colonoscopy with biopsy. Full-thickness excisions can be sewn using TAMIS even if the peritoneum is entered. Full-thickness resection for neoplasms located in the anterior wall of the upper third of the rectum (above the peritoneal reflection) inevitably leads to penetration into the peritoneal cavity. Chen et al. ${ }^{7}$ reported $4(16 \%)$ patients who had an intraoperative peritoneal cavity penetration through the anterior rectal wall. In another study, these patients were informed that trans-abdominal access may be required to close the defect. ${ }^{6}$ In the present study, none of the patients had perforation into the peritoneal cavity. Therefore, neither transabdominal access nor defect closure was required in any of the patients. Fortunately, the full-thickness defect observed in five patients was under peritoneal reflection. Although closure of the defect with clip or suture has been suggested in small series, a meta-analysis evaluated 489 patients and showed that outcomes were not different between patients with or without defect closure. ${ }^{13}$ In this study, we preferred not to stitch up the defect after the resection. In previous studies, some patients were discharged on the surgery day. By contrast, some patients were discharged on the $25^{\text {th }}$ postoperative day because of complications. ${ }^{5}$

\section{Study Limitations}

However, in the present study, the median hospital stay was 1 (1-3) day, which was sufficient and cost effective for this kind of procedure. Postoperative morbidity was recorded in up to $11 \%$ of patients in large series that included haemorrhage, urinary retention, scrotal or subcutaneous emphysema and perirectal abscess. ${ }^{6}$ TAMIS was performed in 20 patients in this study, and no major complication occurred in these patients. TAMIS can be performed in either the lithotomy or prone position. ${ }^{14}$ We preferred the lithotomy position in all patients since this position was mostly preferred by the anaesthesiology team, and we thought that using a $30^{\circ}$ camera facilitates the excision of rectal lesions in any location irrespective of the patient position. Retrospective design, small-sample size and short follow-up period are limitations of this study.

\section{Conclusion}

TAMIS using the SILS port is a safe and effective technique for the treatment of benign rectal lesions. Defect closure is not usually necessary. Further studies with more patients and long-term follow-up are needed.

\section{Ethics}

Ethics Committee Approval: This study was approved by Marmara University Faculty of Medicine Ethics Committee.

Informed Consent: Obtained.

Peer-review: Externally and internally peer reviewed.

\section{Authorship Contributions}

Surgical and Medical Practices: T.K.U., W.A., Concept: T.K.U., W.A., Design: T.K.U., W.A., Data Collection or Processing: T.K.U., W.A., Analysis or Interpretation: T.K.U., W.A., Literature Search: T.K.U., W.A., Writing: T.K.U., W.A.

Conflict of Interest: No conflict of interest was declared by the authors.

Financial Disclosure: The authors declared that this study received no financial support.

\section{References}

1. de Graaf EJR, Burger JWA, van IJsseldijk ALA, Tetteroo GWM, Dawson I, Hop WCJ. Transanal endoscopic microsurgery is superior to transanal excision of rectal adenomas. Color Dis 2011;13:762-767

2. Moore JS, Cataldo PA, Osler T, Hyman NH. Transanal endoscopic microsurgery is more effective than traditional transanal excision for resection of rectal masses. Dis Colon Rectum 2008;51:1026-1031.

3. Atallah S, Albert M, Larach S. Transanal minimally invasive surgery: a giant leap forward. Surg Endosc 2010;24:2200-2205

4. Martin-Perez B, Andrade-Ribeiro GD, Hunter L, Atallah S. A systematic review of transanal minimally invasive surgery (TAMIS) from 2010 to 2013. Tech Coloproctol 2014;18:775-788.

5. Haugvik SP, Groven S, Bondi J, Vågan T, Brynhildsvoll SO, Olsen OC. A critical appraisal of transanal minimally invasive surgery (TAMIS) in the treatment of rectal adenoma: a 4-year experience with 51 cases. Scand J Gastroenterol 2016;51:855-859

6. Lee L, Burke JP, Debeche-Adams T, Nassif G, Martin-Perez B, Monson JRT, Albert MR, Atallah SB.Transanal minimally invasive surgery for local excision of benign and malignant rectal neoplasia. Ann Surg 2018;267:910916.

7. Chen N, Peng Y-F, Yao Y-F, Gu J. Trans-anal minimally invasive surgery for rectal neoplasia: Experience from single tertiary institution in China. World J Gastrointest Oncol 2018;10:137-144.

8. Canda AE, Terzi C, Sagol O, Sarioglu S, Obuz F, Fuzun M. Transanal Single-port Access Microsurgery (TSPAM). Surg Laparosc Endosc Percutan Tech 2012:22:349-353. 
9. Slack T, Wong S, Muhlmann M. Transanal minimally invasive surgery: a initial experience. ANZ J Surg 2014;84:177-180.

10. van den Boezem PB, Kruyt PM, Stommel MWJ, Tobon Morales R, Cuesta MA, Sietses C. Transanal single-port surgery for the resection of large polyps. Dig Surg 2011;28:412-416.

11. Albert MR, Atallah SB, deBeche-Adams TC, Izfar S, Larach SW. Transanal Minimally Invasive Surgery (TAMIS) for local excision of benign neoplasms and early-stage rectal cancer. Dis Colon Rectum 2013;56:301-307.
12. deBeche-Adams T, Nassif G. Transanal minimally invasive surgery. Clin Colon Rectal Surg 2015;28:176-180.

13. Menahem B, Alves A, Morello R, Lubrano J. Should the rectal defect be closed following transanal local excision of rectal tumors? A systematic review and meta-analysis. Tech Coloproctol 2017;21:929-936.

14. Young DO, Kumar AS. Local excision of rectal cancer. Surg Clin North Am 2017;97:573-585 